\title{
PEDAGOGICKO-TVORIVÁ METÓDA THOMASA OSTERMEIERA
}

\section{JITKA GORIAUX PELECHOVÁ}

Divadelná fakulta Akadémie múzických umení, Praha

\begin{abstract}
Abstrakt: Štúdia sa zaoberá špecifickým pracovným procesom, ktorý vyvinul nemecký režisér Thomas Ostermeier so zámerom urobit z hercov aktívnych spolutvorcov svojich inscenácií. Vo svojej práci čerpá z induktívnej metódy Bertolta Brechta a zároveň z odkazu Konstantina Sergejeviča Stanislavského a Vsevoloda Mejerchol’da. Zámerom štúdie je reflektovat nielen samotnú metódu, ale aj jej konkrétnu aplikáciu pri práci so študentmi v rámci workshopu, ktorý Thomas Ostermeier viedol na Divadelnej fakulte Akadémie múzických umení v Prahe.

Klúčové slová: tvorivé herectvo, vedenie hercov, vztahah režisér - herec, induktívna metóda, storytelling, Thomas Ostermeier, Bertolt Brecht, Konstantin Sergejevič Stanislavskij, Anton Pavlovič Čechov
\end{abstract}

Ako sa môže herec stat’ skutočným (spolu)tvorcom inscenácie a neostat' len vykonávatelom režisérových pokynov? Z akých prameňov môže čerpat' vo svojej tvorbe? A aké môžu byt’ nástroje režiséra (pedagóga), ktorý chce svojich hercov (študentov) viest' k samostatnému tvorivému procesu? Nemecký režisér Thomas Ostermeier, už takmer dvadsat rokov šéf prestížnej berlínskej Schaubühne am Lehniner Platz, prehlbuje tieto otázky v rámci svojej práce na vel’mi rozmanitom repertoári. Ostermeier túto metódu pravidelne a systematicky využíva pre vlastnú tvorbu približne od roku 2012, ked' ju naplno rozvinul pri inscenovaní Ibsenovho Nepriatel'a l'udu. Samozrejme, nejde o "recept na tvorbu“, ale skôr o nikdy sa nekončiaci „work in progress" približujúci sa logike umeleckého výskumu, preto Ostermeier metódu d’alej rozvíja a zdokonaluje aj v priebehu práce so študentmi svojich režisérskych seminárov na berlínskej divadelnej škole Ernsta Buscha či formou workshopov, ktoré pravidelne vedie na iných divadelných školách. Jeden z nich prebehol v decembri 2018 na Divadelnej fakulte Akadémie múzických umení v Prahe. Zúčastnili sa na ňom poslucháči Katedry činoherného divadla (d’alej KČD DAMU), herci a režiséri/dramaturgovia, ktorí potom niektoré z tu absolvovaných cvičení použili pri príprave ich prvej absolventskej inscenácie, Čechovovho Višňového sadu v divadle DISK.

\section{Induktívny prístup: dráma ako scénický projekt}

Spojenie systémov hereckej a režijnej práce Bertolta Brechta a Konstantina Sergejeviča Stanislavského, ktoré sa zvyčajne prezentujú ako úplne protichodné, sa môže na prvý pohl'ad zdat' prekvapujúce. Skutočnost', že ich Ostermeier vo svojej práci kombinuje, je popri inom výsledkom jeho osobnej cesty a skúsenosti. V devätdesiatych rokoch absolvoval štúdium réžie na Hochschule für Schauspielkunst Ernst Busch, kde je divadelná výchova založená práve na týchto dvoch pilieroch. Dá sa to napokon vysvet- 
lit aj dejinami tejto akadémie, ktorá bývala hlavnou divadelnou školou východného Nemecka. Podla Stanislavského systému (prípadne podl’a jeho interpretácie zodpovedajúcej požiadavkám socialistického realizmu) sa tam tradične vyučuje už od pätdesiatych rokov 20. storočia, zatial' čo tradícia Brechtovho epického divadla (či opät’ jej určitá vízia podl'a politicko-ideovej situácie) sa na tejto škole udržiava ako jedno zo špecifík východonemeckého divadla. Počas svojho štúdia Ostermeier dokonca sám stál na doskách Berliner Ensemble, a to v réžii Manfreda Kargeho, svojho vedúceho pedagóga a výraznej osobnosti nemeckého epického divadla tzv. druhej generácie Brechtschüller.

Bertolt Brecht formuloval myšlienku induktívnej metódy v eseji z roku 1939 s názvom Postoj vedúceho skúšok (pri induktívnom postupe). ${ }^{1}$ Výraz indukcia tu používa $\mathrm{v}$ protiklade $\mathrm{k}$ dedukcii, ktorá je charakterizovaná postupom od všeobecného $\mathrm{k}$ jednotlivému, teda od vopred vytvorenej a určenej estetickej koncepcie, aplikovanej na konkrétny dramatický text či iný materiál. V induktívnom prístupe sa naopak postupuje od jednotlivého (teda od dramatického textu) k všeobecnému (teda finálnej podobe inscenácie). Tento postup tak nemôže byt’ plodom apriornej predstavy tvorcov, ale sa rozvíja a definuje postupne $\mathrm{v}$ priebehu skúšania na základe spoločného skúmania, objavovania a interpretácie textu. Text sa vníma ako východiskový bod, ktorý však má v sebe len zlomok celej komplexnej skutočnosti, ktorú vytvára jeho autor. Režisér a herci z neho teda musia odvodit' (indukovat') konkrétne vyjadrenie skutočnosti na javisku, a to v spolupráci s celým tvorivým tímom v priebehu skúšok, nie vopred za pracovným stolom: „Vedúci skúšok neprichádza do divadla s nejakou ,myšlienkou' či ,víziou', s určitou ,predstavou o rozostavení hercov na javisku', alebo ,pevne danou výpravou'. Netúži ,uskutočnit’ jednu myšlienku. Jeho úlohou je prebudit’ a usporiadat' hercovu (hudobníkovu, výtvarníkovu atd'.) výkonnost'. Skúšat' preňho neznamená sadit na javisku to, čo už je vopred pevne dané v jeho hlave. Skúšat je preňho príležitost’ vyskúšat’ nové veci.“2

Aké nástroje majú $\mathrm{k}$ dispozícii režisér a herci tohto induktívneho procesu? Pre Ostermeiera je prvotne dôležité čerpat’ z vel'mi precíznej analýzy textu a to (prekvapujúco) v zmysle Stanislavského, teda z rozboru dramatických situácií, daných okolností, úryvkov, úloh a priebežného konania postáv: tento celok nazýva „režisérovým šlabikárom“3. Čo sa týka princípov a ciel’ov, ktorými sa má riadit induktívna práca, vracia sa Ostermeier znova k Stanislavského odkazu. Jedným z prvých momentov spolupráce režiséra s hercami, dramaturgom, scénografom, prípadne d’alšími členmi inscenačného tímu je nájst’ a sformulovat’ jeden hlavný dôvod, prečo inscenovat’ práve tento a nie iný text. Zdôvodnenie sa má podl’a Ostermeiera vojst’ do krátkej formulky, do jednej, maximálne dvoch viet, a musí sa vztahovat na osobnú životnú skúsenost’ zúčastnených umelcov. Spoločná formulácia tohto podstatného dôvodu sa tak vlastne stáva tým, čo je Stanislavského hlavná úloha - s tým rozdielom, že tu nejde o dramatickú postavu a konflikt ako u Stanislavského, ale o celú tvorivú prácu, vrátane spolupráce jednotlivých zložiek inscenácie. V Ostermeierovej induktívnej metóde sa

${ }^{1}$ BRECHT, B. Haltung des Probenleiters (beim induktiven Vorgehen). In Werke, Band 22. Berlin - Weimar - Frankfurt am Main, 1994, s. 597 - 599. Ak nie je uvedené inak, cudzojazyčné zdroje sa citujú v autorkinom preklade.

${ }^{2}$ Tamže, s. 597.

${ }^{3}$ BOENISCH, P. M. - OSTERMEIER, T. The Theatre of Thomas Ostermeier. Abingdon : Routledge, 2016, s. 134 . 


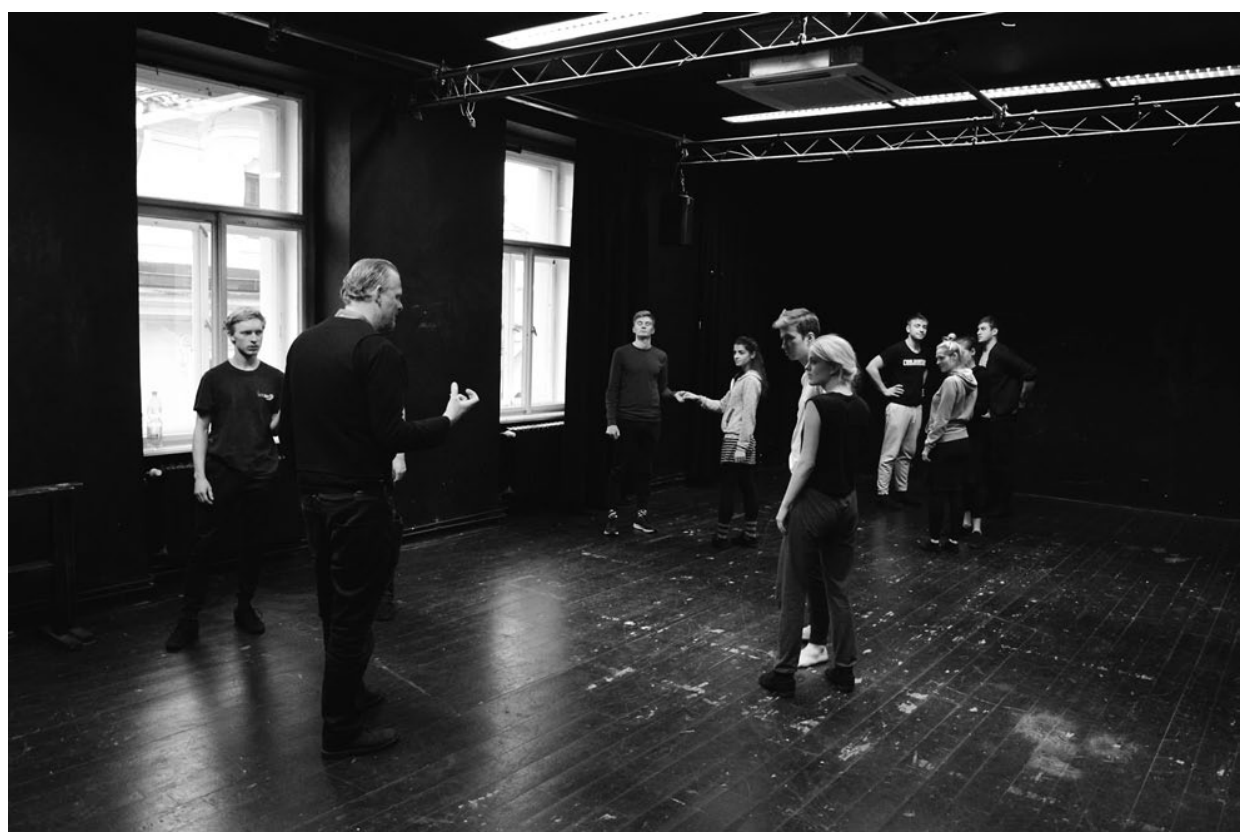

Režisér Thomas Ostermeier so študentmi DAMU počas workshopu. Praha, december 2018. Foto DAMU. Snímka Aminata Keita.

teda interpretácia východiskového textu v zmysle Stanislavského stáva základňou na „skúmanie l’udského správania v určitom historickom, politickom a spoločenskom kontexte ${ }^{\prime 4}$, teda na skúmanie l'udského správania a konania v logike dialektického divadla podla Brechtových úvah.

Práve toto nečakané spojenie medzi prvkami tvorivých prístupov Stanislavského a Brechta vnímali študenti počas workshopu ako zvlášt podnetné. Divadelná výchova KČD DAMU vychádza z vel'kej časti z klúčových prvkov Stanislavského systému: východiskovým bodom javiskového výrazu je dramatické konanie v situáciách, ktoré sa metonymicky vzṫahujú na „skutočné“ l’udské správanie. Dráma sa tak vníma ako scénický projekt, ktorý sa ukončuje až realizáciou a rozvinutím svojej scénickosti na javisku v rámci divadelnej udalosti. Študenti tak vel’mi rýchlo našli spoločný jazyk s Ostermeierom, ktorého induktívna metóda stojí na rovnakých základoch, avšak otvára d’alšie, nové obzory.

Spomínaný rozbor dramatického textu ako scénického projektu je súčastou režisérovej prípravy pred samotným začiatkom skúšania (prípadne s niekol'kými spolupracovníkmi - prekladatel'om, dramaturgom, scénografom). Hlavná otázka, ktorú Ostermeier rozvíjal so študentmi počas workshopu, znela: Ako premenit’ poznatky, ktoré režisér musí mat', ktoré si našiel, kriticky preskúmal a vytvaroval vzhl'adom na celkový projekt, na jasné a použitel'né informácie pre hercov? Na informácie, ktoré by mohli vyvolat' ich vlastnú tvorivost', a nie ich nútili reagovat na nejaké abstraktné

\footnotetext{
${ }^{4}$ Tamže.
} 


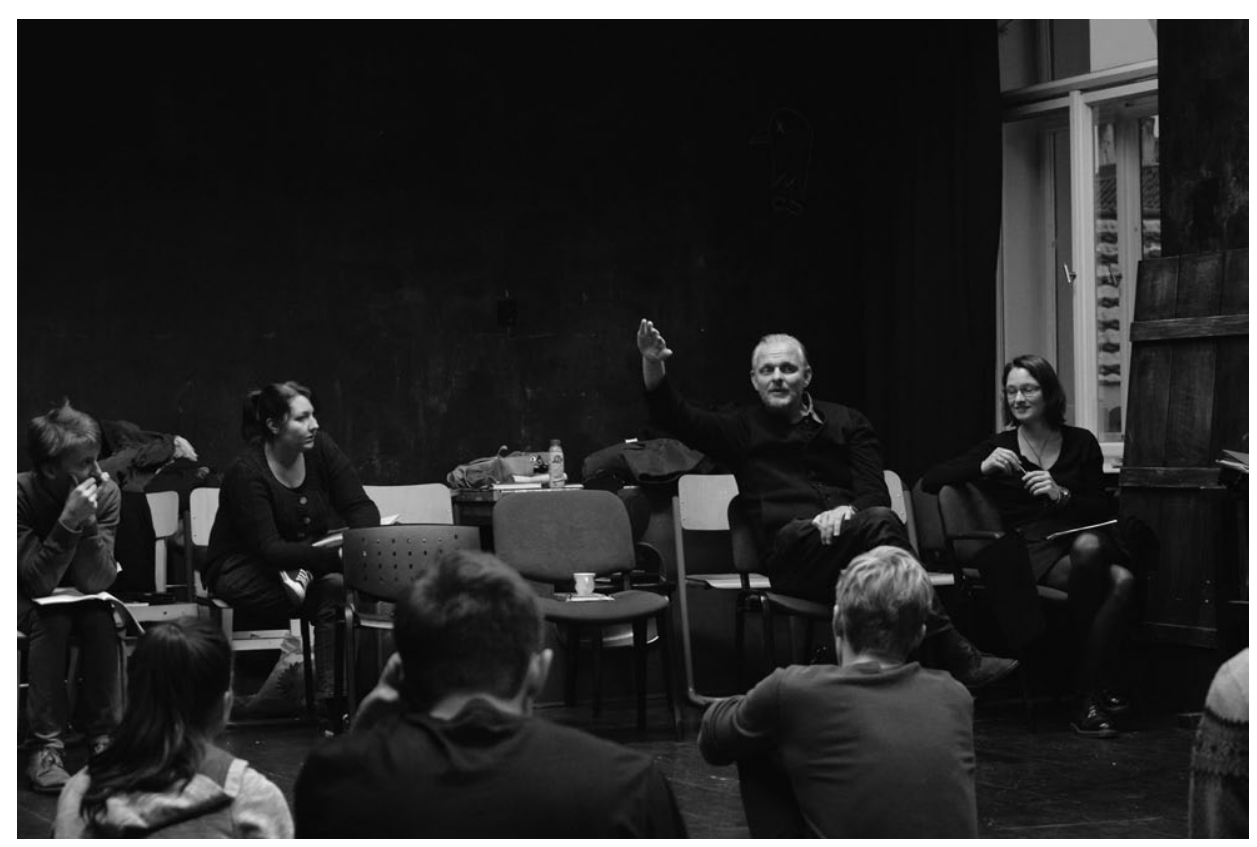

Režisér Thomas Ostermeier so študentmi DAMU počas workshopu. Praha, december 2018. Foto DAMU. Snímka Aminata Keita.

očakávania a predstavy pána režiséra. Ostermeier to formuloval lapidárne: „Herci nemôžu hrat’ myšlienky, nemôžu hrat’ dramaturgiu alebo intelektuálne koncepty. (...) Nie sú to poskytovatelia služieb, ktorí tvoria na objednávku. ${ }^{5}$ Ideálom, ku ktorému by režisér rád dospel, je nemusiet' „vôbec riadit, diktovat', prikazovat', predpisovat', nariad'ovat' ani dávat' povely ", ale naopak, využit rozbor textu podl'a Stanislavského na to, aby vzbudil hereckú tvorivost’ a autentickost' prejavu. Hoci sa to môže zdat' na prvý pohlad paradoxné, Ostermeier tvrdí, že tento rozbor môže pomôct' režisérovi uvol'nit’ sa z pripisovania prehnaného dôrazu na psychologické aspekty a vyhnút sa nebezpečenstvu, že by z nich privel’mi vychádzal pri práci s hercami. „Viest’ hercov prostredníctvom popisných psychologických povelov (,ukáž mi hnev` a pod.) určuje vopred hercom, čo majú urobit. “7 Ostermeier chce namiesto toho stimulovat' ich inšpiráciu a podnecovat' ich $\mathrm{k}$ tomu, aby sa priamo podiel'ali na tvorivom procese. $\mathrm{Na}$ základe induktívneho prístupu (či vnímania drámy ako scénického projektu - podla slovníka Thomasa Ostermeiera alebo študentov DAMU) by sa konania a postoje hercov na scéne mali vždy odvíjat’ od dramatickej situácie, nie od psychológie či emocionálneho stavu postavy.

\footnotetext{
${ }^{5}$ Tamže, s. $143-144$

${ }^{6}$ Tamže, s. 148.

${ }^{7}$ Tamže.
} 


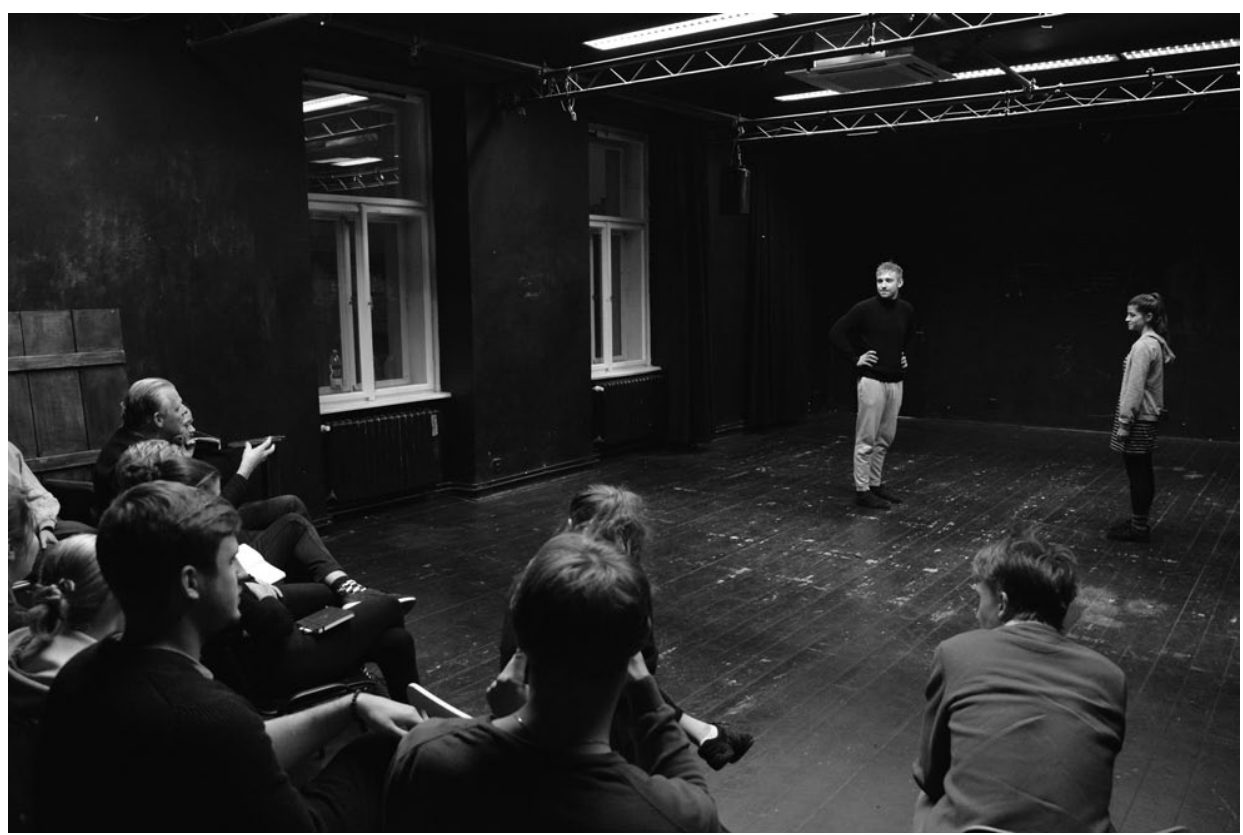

Režisér Thomas Ostermeier so študentmi DAMU počas workshopu. Praha, december 2018. Foto DAMU. Snímka Aminata Keita.

\section{Opakovacie cvičenie podl’a Sandorfa Meisnera}

Ostermeier využíva v čase skúšok konkrétne techniky, procesy a cvičenia smerujúce k vzbudeniu hereckej tvorivosti a autentickosti hereckého prejavu. Priviest' hercov $\mathrm{k}$ úplnému sústredeniu sa na situáciu a v jej rámci na jednotlivé vztahy postáv znamená priviest' ich k sústredeniu sa na javiskových partnerov a na vzájomnú komunikáciu medzi nimi. „Prameňom hercovej tvorivosti môže byt’ ten druhý, ten, ktorý stojí oproti nemu“" pripomína Ostermeier. ${ }^{8}$ Preto sa do prípravnej práce s hercami v logike tréningu pravidelne zarad’uje tzv. opakovacie cvičenie podla Sanforda Meisnera, ktoré sa rozvíja v pároch. Dvaja herci stoja (sedia) oproti sebe a vzájomne sa pozorne sledujú. Jeden z nich potom povie krátku vetu, ktorá vychádza z pozorovania partnera, napr.: „Si nervózny.“ Druhý odpovie jednoducho: „Áno, som nervózny. " Túto krátku výmenu opakujú desat'krát, dvadsatkrát, tridsatkkrát, pričom nechávajú slobodne plynút všetky variácie rytmu, tempa, tónu alebo celkovej energie, ktorá vzišla zo sústavnej vzájomnej komunikácie. V d’alšej fáze cvičenia druhý herec odpovie záporne: „Nie, nie som nervózny.“ Tento naoko minimálny variant je v skutočnosti zásadnou zmenou, pretože sa medzi obidvomi aktérmi objavuje konflikt, v ktorom sa usiluje každý presvedčit partnera o svojej pravde. Situácia sa teda stáva dramatickou. Krátky dialóg sa opät opakuje zdanlivo v kruhu, pokračujúca komunikačná výmena medzi obomi partnermi mu však dáva jasný lineárny vývin.

${ }^{8}$ OSTERMEIER, T. Le théâtre et la peur. Arles : Actes Sud, 2016, s. 116. 


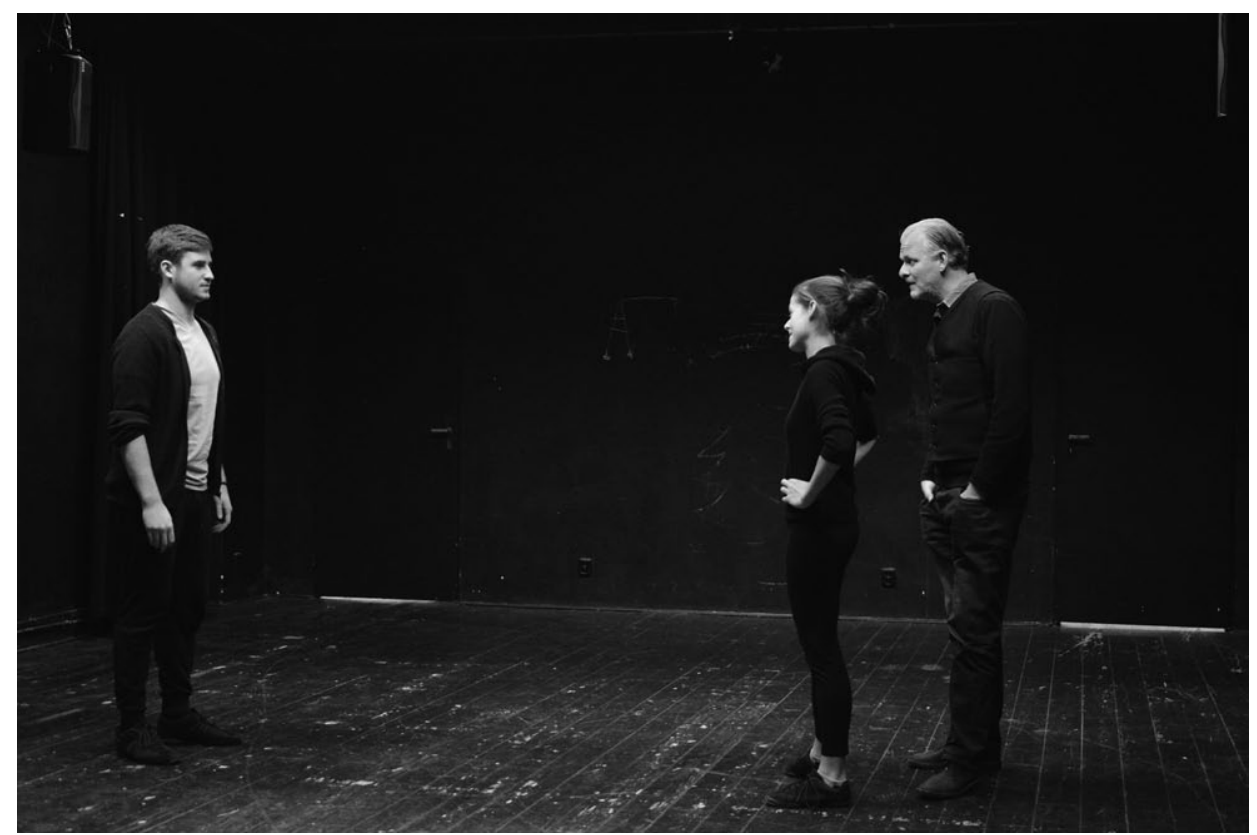

Režisér Thomas Ostermeier so študentmi DAMU počas workshopu. Praha, december 2018. Foto DAMU. Snímka Aminata Keita.

Študenti si v priebehu workshopu mohli prakticky overit', že hlavným ciel'om tohto cvičenia je odviest' primárnu pozornost’ od sémantického obsahu (teda významu, ktorý chcem odovzdat') aj od hercovho „ja“" a sústredit’ sa viac na partnera oproti, na jeho vplyv, na emóciu, ktorú vzbudzuje, na dynamickú energiu, ktorú vysiela; sústredit’ sa na vzájomnú komunikáciu a na to, akým spôsobom sa dá premenit a použit’ ako inšpirácia a materiál na hercovu vlastnú existenciu na javisku. Toto cvičenie vedie hercov na jednej strane $\mathrm{k}$ tomu, aby sa vnorili do prítomného okamihu, a na druhej strane k maximálnej pozornosti voči partnerovi. Povzbudzuje hercovu vlastnú tvorivost’ a zároveň tým pre ňu vytvára ozvučný priestor. Slovami Thomasa Ostermeiera: "Je to akoby obaja herci hrali na jeden hudobný nástroj. ${ }^{\text {}}$

Kým problematika vzájomnej komunikácie v rámci dramatickej situácie bola študentom známa, opakovacie cvičenie, ktoré vnáša do centra hercovej práce jeho vztah k partnerovi (t. j. k tomu druhému, k tým druhým), im otvorilo nový obzor: Človek sa tu chápe a poníma ako spoločenský tvor, ktorý tvorí svoje „ja“ vo vzt’ahu a zo vztahu k tým ostatným, v zásade podl’a brechtovského uhla pohl'adu.

\section{Storytelling}

V opakovacom cvičení preberá Ostermeier metódu vyvinutú americkým hereckým pedagógom Sandorfom Meisnerom. Paralelne s ním však nemecký režisér vy-

\footnotetext{
${ }^{9}$ Tamže.
} 
vinul vlastný typ cvičenia, ktoré často využíva počas skúšania s hercami. Nazýva ho storytelling. Ostermeier v tomto cvičení vychádza zo základnej požiadavky naturalisticko-realistickej činohry, smerujúcej k autentickosti hereckého prejavu. Herci $\mathrm{v}$ postavách by sa $\mathrm{v}$ ideálnom prípade mali správat’ a konat’ $\mathrm{v}$ rámci dramatických situácií tak, akoby sa správali a konali sami za seba (podobne ako u Stanislavského: postava som ja v daných osobnostiach). Otvára sa však otázka, ako sa to v skutočnosti dá dosiahnut. Ako prinútit hercov k tomu, aby si uvedomili, že „pri vyjadrovaní emócií na javisku často podliehajú určitým divadelným modelom (...), že v skutočnom živote reagujeme na niektoré situácie celkom inak, než sme sa to naučili na kurzoch herectva“" ? ${ }^{10}$ Nestačí samé osebe detailne rozobrat’ a pochopit’ situácie, dané okolnosti či dramatické procesy, ked’že herci nemôžu „hrat myšlienky“. Ostermeierova odpoved' znie, že je potrebné nájst’ prepojenie týchto dramatických situácií, konfliktov, okolností, úloh s hercovou reálnou životnou skúsenostou. A práve to je zmysel a účel storytellingu.

Na začiatku storytellingového cvičenia zadá Ostermeier úlohu, ktorá má podobu všeobecnej dramatickej situácie, abstrahovanej z nacvičovanej hry, napr. „chceš niekoho presvedčit, aby urobil niečo zakázané“ alebo „pokúšaš sa niekomu zabránit, aby urobil vel'kú chybu“. ${ }^{11}$ Konkrétne pri skúšaní Nepriatel’a l’udu v Schaubühne am Lehniner Platz navrhol Ostermeier toto zadanie: Vstúpite do miestnosti, kde očakávate, že sú vám všetci naklonení, ale okamžite zistujete, že to tak nie je, že sú naopak všetci proti vám; to sa stane ústrednej postave Ibsenovej drámy dr. Stockmannovi $\mathrm{v}$ jednom z hlavných zvratov hry. V tej chvíli môže akýkolvek herec pridat' vlastnú skúsenost' s podobnou situáciou a po vel’mi krátkej príprave (nie viac ako dve alebo tri minúty, aby to nebolo privel'mi inscenované) ju zahrat’ s ostatnými hercami ako improvizovanú scénku. Jedinou podmienkou je, že musí íst’ o skutočný príbeh, ktorý sa danému hercovi naozaj stal. Toto cvičenie sa síce môže zdat’ rovnaké ako zvyčajné herecké improvizácie v priebehu skúšok, ale v skutočnosti má celkom iný účel. Nie je to príležitost' byt' za každú cenu originálny alebo „tvorivý“, nie je to ani dôvod exhibovat’ svoj život (ten, komu sa situácia naozaj stala a ktorý ju odovzdáva, v nej zvyčajne nehrá). Ostermeier nachádza zmysel a účel tohto cvičenia v spomínanej možnosti vzbudit’ v hercoch autentické správanie a konanie skôr než herectvo. Vzniknutý výstup sa potom podrobí spoločnej diskusii celého súboru, pričom sa zvláštna pozornost’ venuje „telesnému konaniu, tónu hlasu, správaniu a reči, ale aj proxemike medzi jednotlivými hercami atd’." ${ }^{12}$. Postupne sa do výstupu vnáša stále viac prvkov z danej situácie hry, niekedy dokonca aj úryvky dialógov, pričom sa dáva pozor na to, aby pôvodný model správania, konania, reči, gest (t. j. celého prejavu) zostal neporušený, hoci aj vo vhodne zdivadelnenej podobe. Ostermeier sumarizuje: Herci „sa nechávajú celkom ovládnut prítomným okamihom aj danou situáciou, pretože nerozmýšlajú o tom, čo bude d’alej. Texty a dialógy nie sú dané vopred, herci si tak musia udržat’ maximálnu pozornost', tak ako v každodennom živote. Čo viac si môže režisér želat!!"13

${ }^{10}$ OSTERMEIER, T. - GORIAUX PELECHOVÁ, J. Divadlo ztratilo hrdost. [rozhovor]. In Divadelní novi$n y, 2019$, roč. 18, č. 18 , s. 8, 29. 10. 2019.

${ }^{11}$ BOENISCH, P. M. - OSTERMEIER, T. The Theatre of Thomas Ostermeier, s. 156.

12 Tamže.

${ }^{13}$ OSTERMEIER, T. Le théâtre et la peur, s. 115. 
Možný prínos cvičení zhrnul Ostermeier v príklade zo skúšania Čechovovej Čajky (Theâtre Vidy, Lausanne, 2014): „Pri skúšaní posledného dejstva Čajky a výstupu Sorinovho umierania som požiadal hercov o storytellingové cvičenie, v ktorom mali rozohrat’ svoju spomienku na smrt’ milovanej osoby. Situáciu navrhol François Loriguet, ktorý pochádza z hlboko nábožensky založenej francúzskej rodiny, kde nemali deti povolené dotýkat’ sa svojho otca. Po prvýkrát v živote ho objali a pobozkali, až ked' jeho telo ležalo v rakve. Na všetkých to, samozrejme, malo obrovský emocionálny vplyv. Zaujímavé na tom bolo, že François celú situáciu vysvetlil za dve či tri minúty a že herečky, ktoré pri nácviku stelesňovali jeho sestry, sa s jeho otcom nikdy nestretli. Situáciu teda rozohrali na základe zopár pokynov. Pozorovali sme pritom rozpačitost’ alebo dokonca šok, ktorý ich správanie vyvolalo vo zvyšku rodiny. (...) Podl'a zvyčajného klišé by ostatní členovia rodiny mali mat’ súcit s frustráciou, ktorú svojím konaním dávajú najavo dve dospelé dcéry, a lutovat̉ ich. V skutočnosti však $\mathrm{v}$ rámci hl'adania autentického správania vznikla naopak rozpačitost’ z niečoho čudného. Takú pravdu možno nájsţ iba v momente, ked’ sa herci môžu oslobodit’ z režisérovho diktátu. ${ }^{14}$

Popri vlastných experimentoch s týmto cvičením, ktoré reflektuje iná čast̉ tejto štúdie, si študenti DAMU mohli znova skúsit’ dvojdomost’ Ostermeierovho uvažovania. Popísaný proces samozrejme pripomína Stanislavského metódu afektívnej pamäti. Pri hlbšom pohl'ade však zistíme, že sme opät na polceste medzi Stanislavským a Brechtom. Ten, ktorého príbeh sa spracúva, teda "storyteller“, svoj príbeh nehrá, ale demonštruje, a táto pozícia ho približuje k logike epického divadla: „Brechtov uličný výstup je vlastne modelom cielov a zmyslu storytellingových cvičení. ${ }^{\text {15 }} \mathrm{Z}$ perspektívy herca mu storytellingové cvičenie ponúka možnost’ použit', využit’ svoju autobiografickú energiu a zároveň rozvíjat’ pozorovacie a komunikačné schopnosti, ktorým už dalo podnet opakovacie cvičenie podl’a Sandorfa Meisnera. Storytelling teda „,aktivizuje najrôznejšie aspekty hercovej inteligencie tak, aby vložil svoje schopnosti a svoje životné skúsenosti do služieb svojho prejavu, dramatického textu aj celej inscenácie ${ }^{11}{ }^{16} \mathrm{Z}$ herca sa tak naozaj môže stat režisérov tvorivý partner.

\section{Rodinná konštelácia}

Ďalším cvičením, ktoré Ostermeier v priebehu skúšok často rozvíja, je rodinná konštelácia. Pôvodne bola vyvinutá ako prostriedok psychoterapie, tu je však adaptovaná pre trochu iné účely. Hoci by sa v rámci induktívnej metódy mala pozornost' odviest' od hercovho ,ja“ a od psychológie či dokonca biografie jeho postavy, v skutočnosti každý herec potrebuje vel’mi jasne a konkrétne pochopit’ situáciu, svoju postavu, jej vzt’ahy s ostatnými, jej emocionálne naladenie, hierarchické postavenie voči ostatným atd’. Pomocou cvičení rodinnej konštelácie získavajú herci praktický a celkom nepsychologizujúci nástroj na to, aby toto všetko priamo pocítili.

Zadanie je vytvorit’ v priestore živý obraz so všetkými postavami hry. Herci si teda majú nájst’ také priestorové postavenie, ktoré by zodpovedalo ich postave:

${ }^{14}$ OSTERMEIER, T. - GORIAUX PELECHOVÁ, J. Divadlo ztratilo hrdost. [rozhovor]. In Divadelní noviny, s. 8 - 9 .

${ }^{15}$ BOENISCH, P. M. - OSTERMEIER, T. The Theatre of Thomas Ostermeier, s. 157.

${ }^{16}$ Tamže, s. 159. 
komu sú blízko, od koho sú vzdialení atd’. Pozornost’ sa venuje nielen tomu, kde stoja $\mathrm{v}$ priestore (vzhl'adom na ostatných), ale aj tomu, v akej sú pozícii, ktorým smerom sa pozerajú, ako robia gesto, aký majú na tvári výraz a podobne. Tento živý obraz „hercom umožňuje fyzicky, telesne prežit vzt̉ah ich postavy k ostatným, aj konštelácie medzi d’alšími postavami. (...) Hlavným účelom (...) je prebudit’ v nich zmyslové, vnútorné, telesné pochopenie postavy v situácii." ${ }^{17}$ Cvičenia sa samozrejme môžu počas skúšok vracat', lebo vzt’ahy a konštelácie sa môžu vyvíjat' - na základe jednotlivých výstupov hry, ale aj na základe pohl’adu na určité veci, ktoré sa môžu v priebehu skúšok v induktívnej logike zmenit’. Ostermeier apeluje na určitú schopnost', ktorú väčšina z nás uplatňuje v skutočnom živote: bez toho, aby sme o tom premýšlali, väčšinou prirodzene zaujmeme $\mathrm{v}$ priestore voči ostatným postavenie, ktoré zodpovedá našej situácii a našej pozícii v jej rámci. Rovnako - podl’a predpokladu Ostermeiera - sa herci môžu cvičit’ v tom, aby na javisku sami telesne vycítili, ked' ich postavenie nezodpovedá situácii.

\section{Psychofyzický ret’azec konania}

Posledný skúmaný prvok Ostermeierovej režijnej metódy, psychofyzický reł’azec konania, $\mathrm{v}$ podstate rozvíja otázky a problémy postavenia a postoja, ktoré už predznačilo cvičenie rodinnej konštelácie. Hlavným zmyslom retazca konania je povedat’ divákom o čosi viac než len to, čo je napísané v texte. Tento sled telesného konania, ktorý herec rozvíja na javisku, môže vel’mi presne komunikovat’ o psychologickom stave a psychologickej situácii postavy, o jej emocionálnom rozpoložení, o jej vzt’ahoch k ostatným a všeobecne o interpretácii celej dramatickej situácie a procesov, ktoré prebiehajú v jej rámci. Znovu sa z pamäti vynorí klasické zadanie Stanislavského, ktorý žiadal od hercov, aby na javisku telesným konaním rozohrali obsah listu, ktorý dostala ich postava.

Takýto psychofyzický retazec konania uzatváral Ostermeierom inscenáciu Shakespearovej hry Richarda III. (Schaubühne am Lehniner Platz, 2015) a z neho vychádzala dokonca zmena záveru hry. Gloucester tu neumrel na bojisku obklopený nepriatel'mi („Král’ovstvo za koňa!“), ale sám, všetkými opustený na svojej posteli, ked’ padol za obet’ výčitkám svedomia a fantómom tých, ktorých zabil. Jeho predstavitel' Lars Eidinger v tomto výstupe pomätene pobiehal po celom javisku, freneticky okolo seba mával mečom a bojoval s neviditel'nými prízrakmi. Pri tom sa akoby sám smrtel’ne poranil a nakoniec padol vyčerpaný na postel'. V celkom záverečnom obraze inscenácie si pripevnil k nohe lano, ktoré ho vynieslo nad stred javiska. Tu sa zavesený dolu hlavou hojdal a otáčal okolo vlastnej osi ako výsek hovädzieho mäsa na bitúnku, až kým nepadla opona. Celá zmena interpretácie dramatickej situácie na konci hry sa teda zaobišla bez akejkolvvek zmeny textu, a pritom bola pre divákov celkom jasne zrozumitel'ná. Ostermeierovými slovami, „retazec psychofyzického konania dáva hercovi príležitost' rozvíjat' konkrétne herecké akcie, a nie sa zameriavat' na nehmatatel'né vyjadrenia emócií, kde dominujú iné prístupy k vedeniu hercov“. ${ }^{18}$

Základný princíp vyjadrovania vnútorného stavu postavy prostredníctvom hercovho vonkajšieho konania nás znovu vracia k požiadavkám naturalisticko-realistic-

\footnotetext{
17 Tamže, s. 16.

18 Tamže, s. 171.
} 


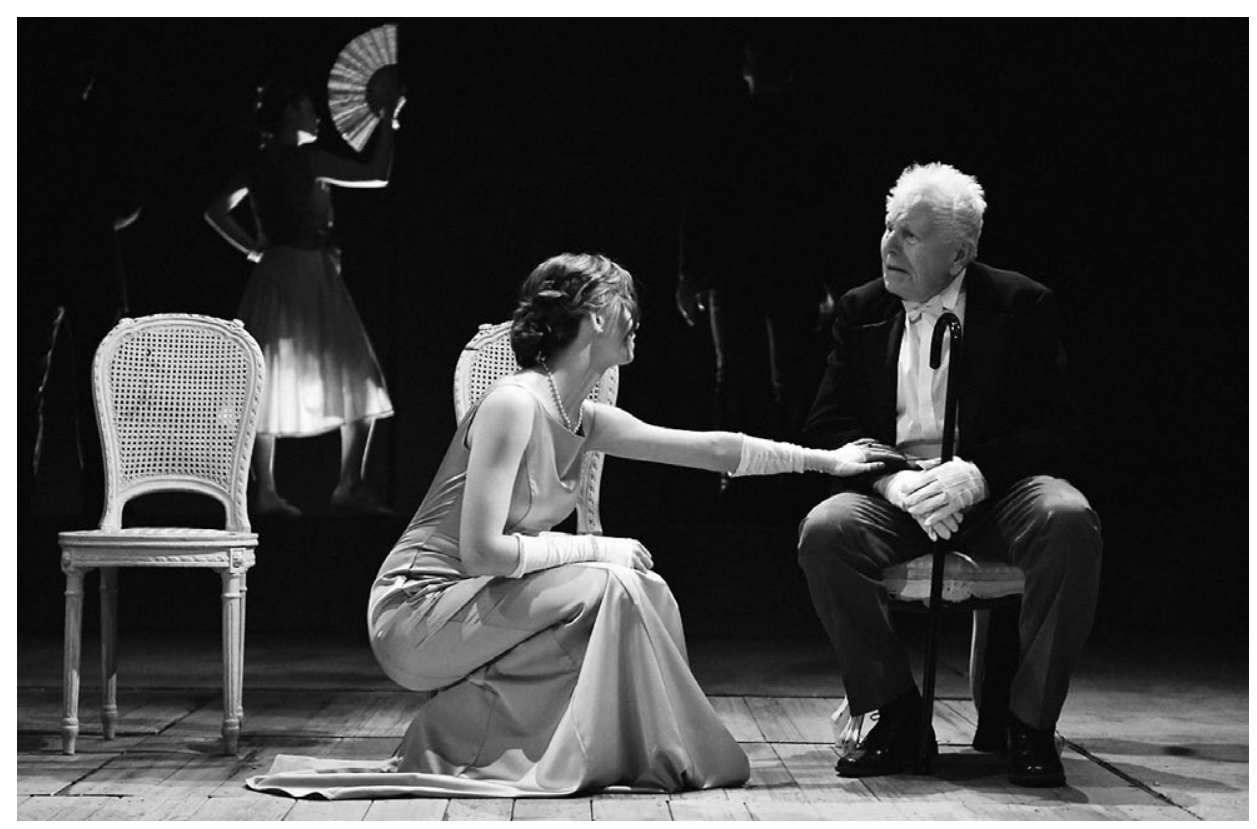

Anton Pavlovič Čechov: Višňový sad. DISK, premiéra 18. 3. 2019. Réžia Aminata Keita. Eliška Zbranková (Ranevská), Dalimil Klapka (Firs). Foto DISK. Snímka Aminata Keita.

kého divadla, ktorého režiséri povzbudzovali hercov, aby funkčne využívali výpravu aj rekvizity. V Stanislavského systéme je táto technika najviac spätá so scénickým vyjadrením podtextu. Rovnaký princíp však rozvíjala aj anti-naturalistická avantgarda $-\mathrm{v}$ dvadsiatych rokoch 20. storočia sa vo forme biomechaniky stal jedným zo základných stavebných kameňov Mejerchol’dovho „štylizovaného divadla“. Thomas Ostermeier sa s Mejerchol’dovým odkazom zoznámil počas štúdia v divadelnej škole Ernsta Buscha, kde sa stretol s Gennadijom Bogdanovom, žiakom Nikolaja Kustova, ktorý bol jedným z Mejerchol'dových hercov, zameraných práve na biomechaniku.

Skúšky Čechovovho Višňového sadu (DISK, 2019), prvej absolventskej inscenácie študentov 3. ročníka herectva a 1. ročníka magisterského štúdia réžie a dramaturgie KČD DAMU, sa začali v januári 2019, teda niekol'ko týždňov po workshope, ktorý študenti spoločne absolvovali. Zaradenie experimentov so storytellingovými cvičeniami do tvorivého procesu nebolo vopred dané, išlo o reakciu na situáciu, v ktorej sa ocitol súbor po prvých dvoch týždňoch intenzívnych čítacích skúšok. Mladí herci, ktorí sa už pri ohlásení titulu ich prvej inscenácie v divadle DISK zl’akli "kolosu“, akým sa čechovovská dráma môže javit', stále viac podliehali obavám z privel'mi ambicióznej úlohy. Tie neupokojila ani prvá fáza čítaných skúšok; naopak, paralýza hercov rástla úmerne s prenikaním do Čechovovho textu a komplexnosti i protikladov jeho postáv. Režisérka Aminata Keita a dramaturg Jaroslav Jurečka teda nevyhnutne potrebovali zvrátit’ tento vývin situácie, ktorá akoby smerovala do slepej uličky, k blokovaniu hercov a strate vzájomnej dôvery. Spomienky na workshop, ktorý celý ročník vyhodnotil ako prínosný a zaujímavý, boli pozitívnym tmelom súboru. Popri bezprostrednej práci s Ostermeierom študenti videli i filmový dokument, ktorý 


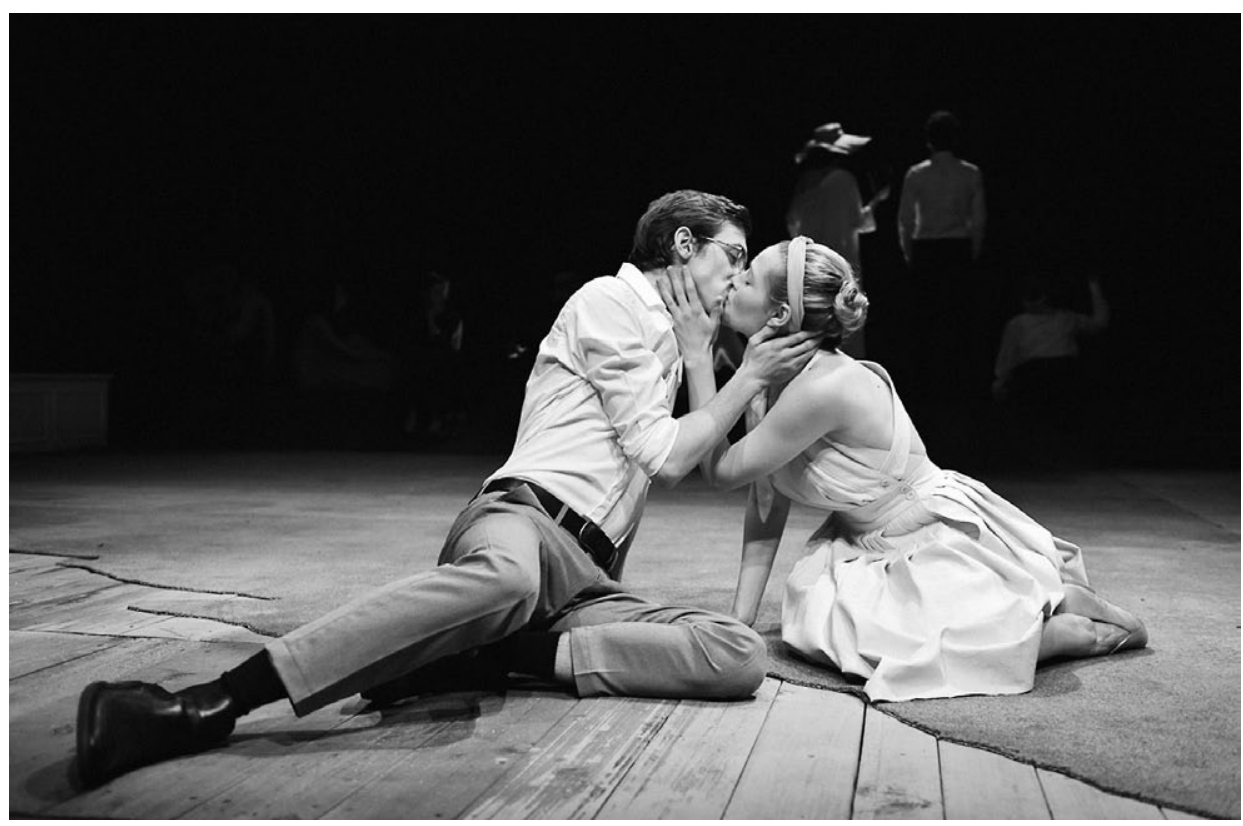

Anton Pavlovič Čechov: Višňový sad. DISK, premiéra 18. 3. 2019. Réžia Aminata Keita. Pavel Čeněk Vaculík (Jaša), Zuzana Novotná (Duňaša). Foto DISK. Snímka Aminata Keita.

zaznamenáva jeho skúšanie Čajky, a teda aj možnost’ využitia storytellingových cvičení pri javiskovom spracovaní Čechovovej drámy. ${ }^{19}$ To, že na sériu čítaných skúšok nadviazalo niekol'ko dní experimentov so storytellingom, bolo zo strany režisérky a dramaturga síce spontánne, pritom však strategické a logické rozhodnutie.

Ako podklad pripravila Aminata Keita zoznam dramatických situácií vol'ne inšpirovaných situáciami drámy, napr. „stretnutie po rokoch“ alebo „ked” som povedal niečo, za čo som sa potom hanbil“. Na začiatku práce nevysvetl’ovala hercom vzt’ah ku konkrétnym situáciám z Višňového sadu, v priebehu rozvíjania situácie sa totiž postupne objavil sám. Iniciatíva zverejnit’ príbeh z vlastného života bola čisto dobrovolná, rozohrávania scénok sa ale zúčastňoval celý súbor. Počas štvorhodinových denných skúšok stihol zvyčajne spracovat’ štyri až pät’ situácií, z ktorých sa maximálne jedna ukázala ako (prí)nosná. Tú potom kolektív opakovane rozohrával s prípadnými variáciami či premenami obsadenia, pričom po každom z nich nasledovala spätná väzba od režisérky i dramaturga a tiež herecké diskusie. Pre Aminatu Keita bola táto fáza skúšania vel'mi náročná, a to nielen pre neustále intenzívne zapojenie a nutnost' reagovat', ale aj z pohl'adu obhajoby zmyslu práce pred hereckým súborom. Experiment však napokon splnil účel. Herci si postupne na konkrétnych príkladoch začali uvedomovat', že aj zdanlivo banálne situácie môžu byt’ divadelne zaujímavé a že protiklady čechovovských postáv, ktoré sa nedajú pochopit’ inak len podl'a vlastnej životnej skúsenosti, môžu mat silný scénický potenciál.

${ }^{19}$ CUVILLIER, J. Thomas Ostermeier, Insatiable théâtre. (C) Compagnie des Indes - ARTE TV, 2016. 


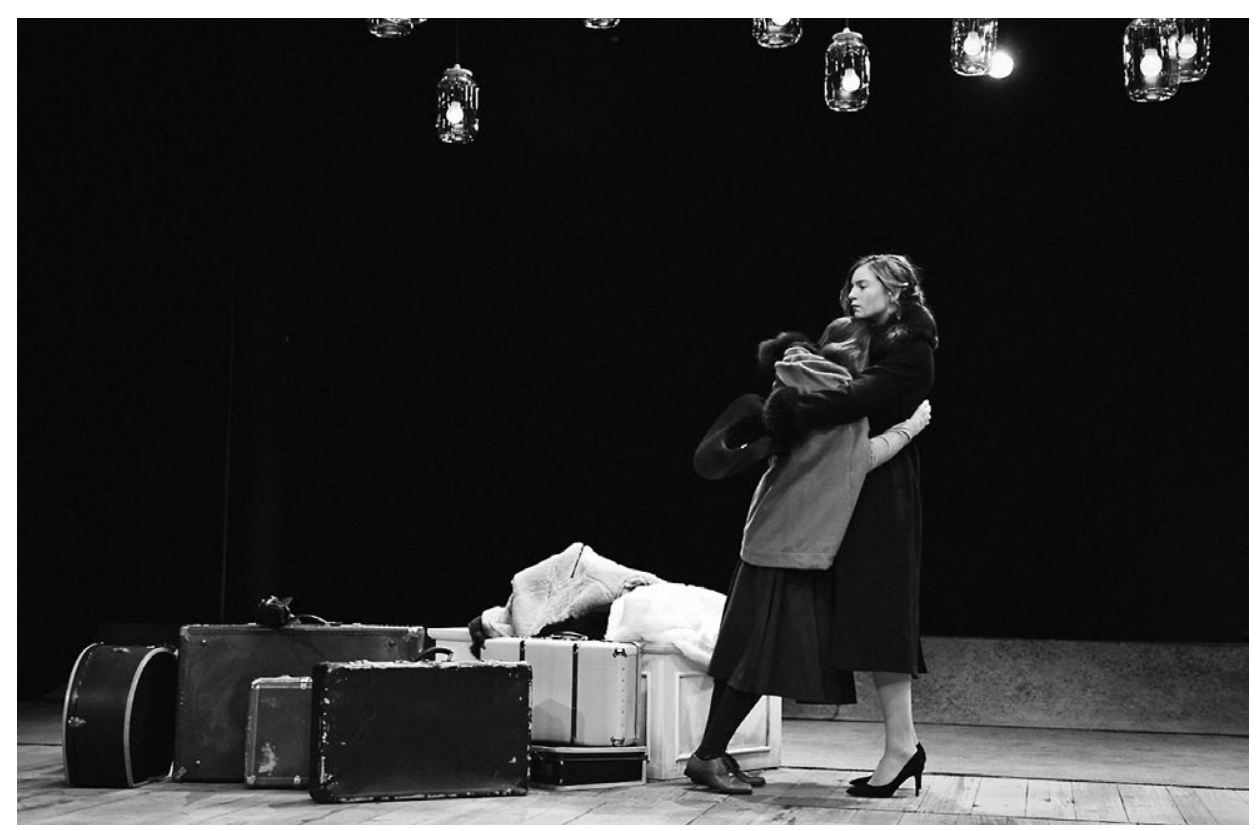

Anton Pavlovič Čechov: Višňový sad. DISK, premiéra 18. 3. 2019. Réžia Aminata Keita. Zuzana Černá (Varja), Eliška Zbranková (Ranevská). Foto DISK. Snímka Aminata Keita.

Najvýraznejší storytellingový výstup, ktorý zároveň znamenal plynulý prechod ku klasickému skúšaniu jednotlivých situácií drámy, rozvíjal námet stretnutia po mnohých rokoch odlúčenia. Jedna z herečiek sa podelila so spomienkou na stretnutie s otcom, pri ktorom jej odlúčení rodičia ostali stát d’aleko od seba a ona - malé diet’a - musela sama prekonat' vzdialenost' od matky k otcovi a objat’ otca. Napätie medzi statickým a dynamickým prístupom k stretnutiu, medzi zvítaním pasívne prijatým a zvítaním ako aktívnym konaním, bolo natol'ko scénické, že sa v rolách napokon vystriedal celý súbor. Toto zvítanie s otcom, ktoré vlastne bolo zvítaním so sadom, sa stalo spoločným zážitkom všetkých hercov, z ktorého mohla nasledovne vytrysknút’ zjednocujúca spoločná predstavivost’ pre celú tvorivú prácu. Vo finálnej podobe inscenácie sa nenachádza žiadny konkrétny prvok storytellingových cvičení rozvíjaných v priebehu skúšok. Ich zmyslom a cielom bolo nájst’ spoločný prístup, spoločný jazyk na tematizáciu jednotlivých situácií či konaní a stimulovat tak skutočne induktívny inscenačný prístup.

Je zaujímavé, že prínos, ktorý mali experimenty so storytellingom pre študentov, nezodpovedá hlavnému prínosu, ktorý od tejto metódy očakáva jej autor. Thomas Ostermeier ho vidí predovšetkým v nájdení autentickosti l’udského správania a konania v životných situáciách, ktorú chce potom využit’ ako východiskový bod divadelno-tvorivej práce s hercami. V skúškovom procese Višňového sadu však režisérka a dramaturg vnímali túto autentickost', ktorú storytellingové cvičenia jednoznačne povzbudzujú, skôr ako problém. Od začiatku sa tým totiž nastavila silná civilnost' prejavu, ku ktorému sa v d’alších fázach skúšok len tažko pridávali väčšie gestá, divadelnost', odstup. 


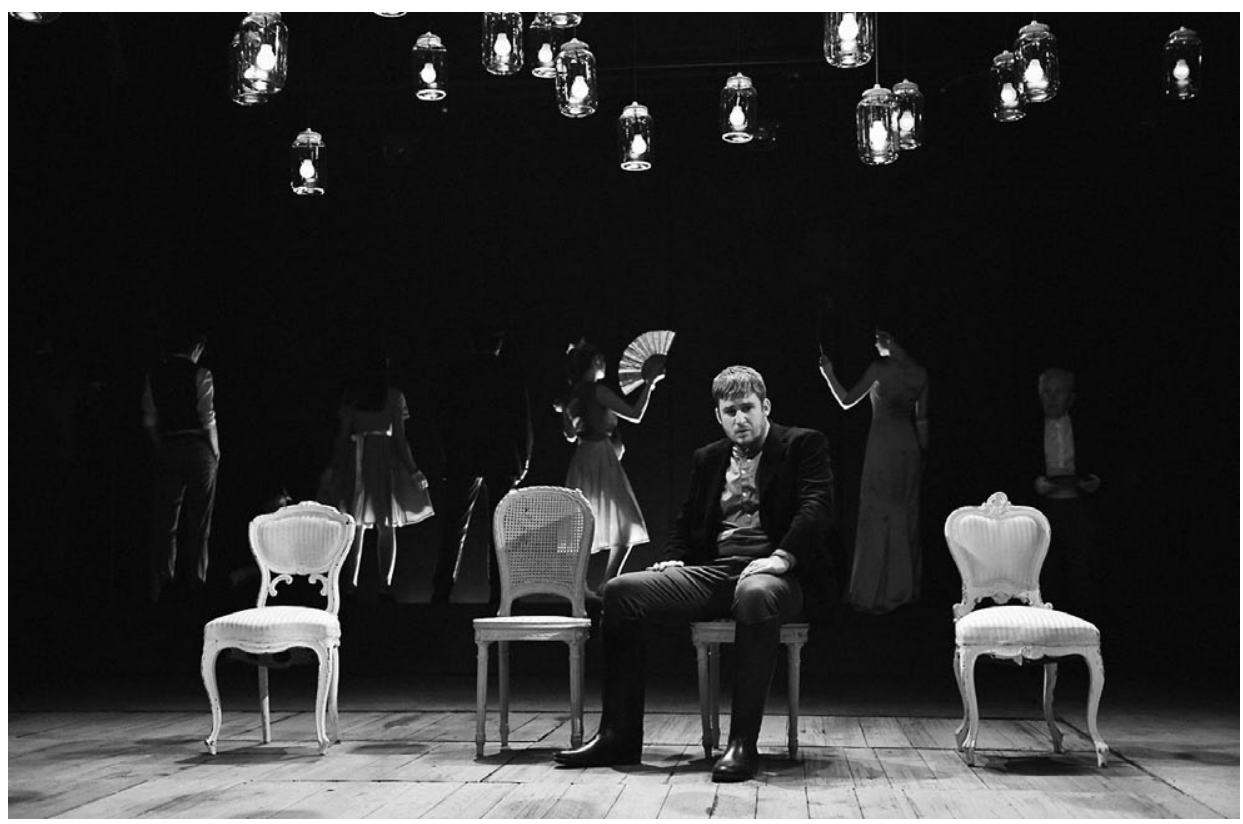

Anton Pavlovič Čechov: Višňový sad. DISK, premiéra 18. 3. 2019. Réžia Aminata Keita. David Krchňavý (Simeonov-Piščik). Foto DISK. Snímka Aminata Keita.

Celkovo všetci zo súboru ohodnotili skúsenost’ so storytellingom pozitívne, no jasne si uvedomovali potrebu kontextu vhodného na jeho rozvíjanie. Prvým aspektom sú vzájomné vzt’ahy medzi zúčastnenými. Ten bol na začiatku skúšok Višňového sadu naplnený: členovia ročníka sa vzájomne dobre poznali a spájali ich pozitívne skúsenosti z predchádzajúcej spolupráce. No v prípade nesúrodého či menej zjednoteného súboru by sa tento druh experimentu mohol l'ahko stat' „časovanou bombou“. Druhým aspektom je zvyčajná divadelná prevádzka. Je celkom zrejmé, že ak majú storytellingové cvičenia priniest’ svoje plody, nemožno im v skúškovom procese vyčlenit’ menej než šest' až osem dní. To však v prípade bežného harmonogramu, rozvrhnutého do ôsmich až deviatich týždňov, môže predstavovat' neprekonatel'ný problém. Tento tlak pocítili aj študenti, ktorým práve tých osem dní venovaných storytellingu potom "chýbalo".

\section{Záver}

Ostermeierovu pedagogicko-tvorivú metódu samozrejme nemožno zjednodušit’ iba na spomínané prvky, avšak sú jej základnými stavebnými kameňmi. Meisnerovo opakovacie cvičenie, storytelling a rodinná konštelácia umožňujú hercom rozvíjat’ na javisku autentickejšie správanie i celkový prejav, stimulujú ich predstavivost̉ tým, že im umožňujú čerpat z vlastných skúseností a zážitkov, čím sa majú stat’ režisérovými tvorivými partnermi. Tieto cvičenia podl'a Ostermeiera „,v čase skúšok robia priestor na to, aby mohol režisér delegovat’ svoju prácu hercom, ich umeniu, ich predstavivos- 
ti a ich odbornosti“ ${ }^{20}$ Zároveň táto metóda umožňuje hercom nevychádzat’ vo svojej práci z premenlivej psychiky, ale z hmotnej, telesnej skutočnosti javiska a z komunikácie a výmeny energií medzi javiskovými partnermi. Pritom sa ale nevyhýba vyjadreniu psychologických a emocionálnych stavov postáv, napr. formou psychofyzického ret’azca konania. Spoločným zámerom cvičení je vyhnút’ sa falošnej divadelnosti a pritom zdôraznit’ artistnost' jazyka divadelného javiska.

Pre študentov predstavovalo stretnutie s Ostermeierovou metódou konkrétne prehĺbenie ich divadelnej výchovy. V rámci nej sú vedení k skúmaniu l'udského spolužitia i k záujmu o vnútornú dramatickost’ každodenného správania, ktoré môže vyústitł do dramatických situácií, v ktorých sa ludia rozhodujú - vedome či nevedome, zámerne či inštinktívne, a sú nútení - konkrétne a niekedy aj neodvolatel'ne - konat'. $\mathrm{V}$ tomto zmysle študenti intenzívne vnímali práve možnost’ prepojenia prístupov Brechta a Stanislavského, v teórii tak často stavaných proti sebe, vd’aka čomu mohli vnímat' svoju reflexiu l'udského spolužitia nielen ako obraz skutočnosti, ale aj ako umelý a umelecký výraz ich procesov a mechanizmov.

Z češtiny preložil Miloš Mistrík

\section{THOMAS OSTERMEIER'S PEDAGOGICAL AND CREATIVE METHOD}

\section{Jitka GORIAUX PELECHOVÁ}

How does an actor become the creator of his own art, rather than performer of the stage director's instructions? What are the creative sources he can call upon? And what are the tools of a stage director (pedagogue), willing to guide his (student) actors to an autonomous creative process? For the sake of finding answers to these questions Thomas Ostermeier has developed a specific working process that rests on the Brechtian inductive method, but it also contains a variation of many elements of Stanislavsky's system and of Meyerhold's legacy. The stage director's objective, while employing this method, is, in his own words "not to direct at all, not to dictate, not to order, prescribe, tell or instruct" but quite the contrary "to delegate [his] work to actors, to their art, to their imagination, and to their expertise". The paper not only aims at describing this method, but also at reflecting its concrete application during a workshop led by Ostermeier, the target group being the students of DAMU in Prague.

Štúdia je príspevkom k projektu APVV č. 15-0764 Slovenské divadlo a súčasná európska divadelná kultúra - kontinuita a diskontinuita.

${ }^{20}$ BOENISCH, P. M. - OSTERMEIER, T. The Theatre of Thomas Ostermeier, s. 157. 


\section{BIBLIOGRAFIA}

BOENISCH, Peter M. - OSTERMEIER, Thomas. The Theatre of Thomas Ostermeier. Abingdon : Routledge, 2016. 276 s. ISBN-10, 1138914479; ISBN-13, 978-1138914476.

BRECHT, Bertolt. Haltung des Probenleiters (beim induktivem Vorgehen). In Werke. Band 22. Berlin - Weimar - Frankfurt am Main, 1994. 1168 s. ISBN 978-3-518-40082-1.

CUVILLIER, Jérémie. Thomas Ostermeier, Insatiable théâtre. [film]. La Compagnie des Indes ARTE TV, 2016. 57 minút.

GORIAUX PELECHOVÁ, Jitka. Divadlo Thomase Ostermeiera. Na cestě za novým realismem. Praha : KANT, 2014. 224 s. ISBN 9788074371462.

OSTERMEIER, Thomas - GORIAUX PELECHOVÁ, Jitka. Divadlo ztratilo hrdost. [rozhovor]. In Divadelní noviny, 2019, roč. 18, č. 18, s. 8 - 9, 29. 10. 2019. ISSN 1210-471X.

OSTERMEIER, Thomas. Le Théâtre et la peur. Ed. Jitka Goriaux Pelechová a Georges Banu. Arles : Acted Sud, 2016. 128 s. ISBN-10, 2330039875; ISBN-13, 978-2330039875.

Jitka Goriaux Pelechová

Divadelní fakulta AMU

Karlova 26

11665 Praha 1

Česká republika

e-mail: jitkagoriaux.pelechova@damu.cz 